Jurnal MAKSIPRENEUR, Vol. VI, No. 1, Desember 2016, hal. 67 - 76

\title{
PENGARUH MOTIVASI KERJA DAN DISIPLIN KERJA TERHADAP KINERJA PEGAWAI
}

\author{
Heriyanto (anto.hery94@ymail.com) \\ Siti Noor Hidayati (datik_ng@yahoo.com) \\ Fakultas Ekonomi Universitas Proklamasi 45
}

\begin{abstract}
Performance is the work result of the employees to achieve of some company goals.The purpose of this researches is to determine the effect of work motivation and work discipline the performance as partial and simultaneous at the BMD Institute. The population in this research a total of 70 employees that is also a sample of all the population in that office. Research using multiple regression analysis. The result showed work motivation and work discipline a significant positive effect on employee performance. It was also concluded that work discipline variable dominanly influenced on employee performance compared to work motivation.
\end{abstract}

Keyword: work motivation, work discipline, employee performance

\section{PENDAHULUAN}

Manusia merupakan sumber daya penting dalam mencapai tujuan organisasi yang mempunyai perbedaan karakteristik dengan sumber daya lainya. Manusia dikatakan sebagai sumber daya penting karena bagaimana pun canggihnya teknologi yang ada, manusia merupakan pelaku utama dalam teknologi itu sendiri. Sumber daya manusia (SDM) di dalam suatu organisasi/perusahaan merupakan suatu yang esensial untuk menjalankan roda organisasi/perusahaan/lembaga untuk mencapai tujuannya. Pada umumnya kehidupan di dalam organisasi/perusahaan/lembaga, apapun bentuk dan sifatnya, baik yang bergerak di bidang perdagangan maupun bidang jasa, akan selalu berusaha mencapai tujuan yang telah ditetapkan sebelumnya secara efektif dan efisien.

Karyawan/pegawai/pekerja/buruh adalah makhluk sosial yang menjadi kekayaan utama bagi setiap organisasi. Pekerja/buruh adalah setiap orang yang bekerja dengan menerima upah atau imbalan dalam bentuk lain (UU RI No.13 Tahun 2003 tentang ketenagakerjaan). Pegawai/karyawan menjadi pelaku yang menunjang tercapainya tujuan organisasi, mempunyai pikiran, perasaan dan keinginan yang dapat mempengaruhi sikapsikapnya terhadap pekerjaan. Karyawan adalah orang penjual jasa (pikiran dan tenaga) dan dapat kompensasi yang besarnya telah ditetapkan terlebih dahulu (Malayu SP Hasibuan, 2012). Keberhasilan suatu perusahaan sangat dipengaruhi oleh kinerja individu karyawan, setiap perusahaan akan selalu berusaha untuk mendapatkan kinerja terbaik dari karyawan, dengan harapan apa yang menjadi tujuan perusahaan akan tercapai. Mangkunegara (2005) berpendapat bahwa kinerja adalah hasil kerja secara kualitas dan kuantitas yang dicapai oleh seorang pegawai dalam melaksanakan tugas sesuai dengan tanggung jawab yang diberikan kepadanya. 
Kinerja menurut Hasibuan (2012), adalah merupakan suatu hasil kerja yang dicapai seseorang dalam melaksanakan tugas-tugasnya atas kecakapan, usaha dan kesempatan. Berdasarkan paparan di atas kinerja adalah suatu hasil yang dicapai seseorang dalam melaksanakan tugas-tugas yang didasarkan atas kecakapan, pengalaman dan kesungguhan serta waktu menurut standar dan kriteria yang telah ditetapkan sebelumnya. Menurut Anwar Prabu Mangkunegara (2005), pengertian kinerja (prestasi kerja) adalah hasil kerja secara kualitas dan kuantitas yang dicapai oleh seorang pegawai dalam melaksanakan tugasnya sesuai dengan tanggung jawab yang diberikan kepadanya. Menurut Rivai (2005) kinerja merupakan perilaku yang nyata yang ditampilkan setiap orang sebagai prestasi kerja yang dihasilkan oleh pegawai sesuai dengan perannya dalam perusahaan. Sedangkan menurut Robins ( 2006) kinerja karyawan merupakan sebuah fungsi interaksi kemampuan, motivasi dan peluang untuk bekerja.

Umar dalam Mangkunegara (2005) membagi aspek-aspek kinerja sebagai berikut, "Mutu pekerjaan, kejujuran karyawan, inisiatif, kehadiran, sikap, kerjasama, keandalan, pengetahuan tentang pekerjaan, tanggung jawab, dan pemanfaatan waktu kerja." Sedang Mitchell (dalam Sedarmayanti (2001) menyatakan bahwa kinerja meliputi beberapa aspek, sebagai berikut: Kualitas kerja (Quality of work), Ketepatan (Promptness), Inisiatif (Initiative), Kemampuan (Capability) dan Komunikasi (Communication). Kinerja karyawan dipengaruhi oleh beberapa faktor baik yang berhubungan dengan tenaga kerja itu sendiri maupun berhubungan dengan lingkungan perusahaan atau organisasi. Wexley dan Yukl (2000), mengidenfikasi faktor - faktor yang mempengaruhi kinerja di antaranya adalah motivasi dan disiplin kerja.

Motivasi menurut Mulyasa (2003) adalah tenaga pendorong atau penarik yang menyebabkan adanya tingkah laku ke arah suatu tujuan tertentu. Peserta didik akan bersungguh-sungguh karena memiliki motivasi yang tinggi. Seorang siswa akan belajar bila ada faktor pendorongnya yang disebut motivasi. Mangkunegara (2005) menyatakan : "motivasi terbentuk dari sikap (attitude) karyawan dalam menghadapi situasi kerja di perusahaan (situation). Motivasi merupakan kondisi atau energi yang menggerakkan diri karyawan yang terarah atau tertuju untuk mencapai tujuan organisasi perusahaan. Sikap mental karyawan yang pro dan positif terhadap situasi kerja itulah yang memperkuat motivasi kerjanya untuk mencapai kinerja maksimal".

Menurut teori Hezberg ada dua faktor yang mendorong karyawan termotivasi yaitu faktor intrinsik yaitu daya dorong yang timbul dari dalam diri masing-masing orang, dan faktor ekstrinsik yaitu daya dorong yang datang dari luar diri sesorang, terutama dari organisasi tempat dia bekerja. Jadi karyawan yang terdorong secara intrinsik akan menyenangi pekerjaan yang memungkinnya menggunakan kreaktivitas dan inovasinya, bekerja dengan tingkat otonomi yang tinggi dan tidak perlu diawasi dengan ketat. Kepuasan di sini tidak terutama dikaitkan dengan perolehan hal-hal yang bersifat materi. Sebaliknya, mereka yang lebih terdorong oleh faktor-faktor ekstrinsik cenderung melihat kepada apa yang diberikan oleh organisasi kepada mereka dan kinerjanya diarahkan kepada perolehan hal-hal yang diinginkannya dari organisasi (Sondang, 2002). Adapun yang merupakan faktor motivasi menurut Herzberg dalam Hasibuan (2012) adalah: pekerjaan itu sendiri (the work it self), prestasi yang diraih (achievement), peluang untuk maju (advancement), pengakuan orang lain (ricognition), tanggung jawab (responsible).

Disiplin menurut Fathoni (2006), adalah kesadaran dan kesediaan seseorang menaati semua peraturan dan norma-norma sosial yang berlaku. Simamora (2006) menyatakan bahwa : "Disiplin adalah prosedur yang mengoreksi atau menghukum bawahan karena 
melanggar peraturan atau prosedur. Menurut Asmirasih (2006) Disiplin merupakan suatu kekuatan yang berkembang di dalam tubuh pekerja sendiri yang menyebabkan dia dapat menyesuaikan diri dengan sukarela kepada keputusan-keputusan, peraturan-peraturan, dan nilai-nilai tinggi dari pekerjaan dan tingkah laku. Disiplin menurut Bejo Siswanto (2005) adalah : "Suatu sikap menghormati, menghargai, patuh, dan taat terhadap peraturanperaturan yang berlaku, baik yang tertulis maupun tidak tertulis serta sanggup menjalankannya dan tidak mengelak untuk menerima sanksi-sanksinya apabila ia melanggar tugas dan wewenang yang diberikan kepadanya" Muchdarsyah Sinungan (2000) menjelaskan : "Disiplin kerja sebagai suatu sikap mental yang tercermin dalam perbuatan atau tingkah laku perorangan, kelompok atau masyarakat berupa kepatuhan atau ketaatan terhadap peraturan-peraturan yang ditetapkan baik oleh pemerintah atau etik, norma, dan kaidah yang berlaku dalam masyarakat untuk tujuan tertentu". Sondang P. Siagian (2005) juga berpendapat bahwa: "Pendisiplinan pegawai adalah suatu bentuk pelatihan yang berusaha memperbaiki dan membentuk pengetahuan, sikap dan perilaku pegawai sehingga para pegawai tersebut secara sukarela berusaha bekerja secara kooperatif dengan pegawai yang lainnya".

Menurut Hasibuan (2012) "Kedisiplinan adalah kesadaran dan kesediaan seseorang mentaati semua peraturan perusahaan dan norma-norma sosial yang berlaku. Kedisiplinan harus ditegakkan dalam suatu organisasi perusahaan. Tanpa dukungan disiplin karyawan yang baik, sulit bagi perusahaan untuk mewujudkan tujuannya. Jadi, kedisiplinan adalah kunci keberhasilan suatu perusahaan dalam mencapai tujuannya. Kedisiplinan merupakan fungsi operatif MSDM yang terpenting karena semakin baik disiplin karyawan, semakin tinggi prestasi kerja yang dapat dicapainya. Tanda disiplin karyawan baik, sulit bagi organisasi perusahaan mencapai hasil yang optimal. Disiplin yang baik mencerminkan besarnya rasa tanggung jawab seseorang terhadap tugas-tugas yang diberikan kepadanya. Hal ini mendorong gairah kerja, semangat kerja, dan terwujudnya tujuan perusahaan, karyawan, dan masyarakat. Oleh karena itu, setiap manajer selalu berusaha agar para bawahannya mempunyai disiplin yang baik. Seorang manajer dikatakan efekif dalam kepemimpinannya, jika para bawahannya berdisiplin baik. Untuk memelihara dan meningkatkan kedisiplinan yang baik adalah hal yang sulit, karena banyak faktor yang mempengaruhinya. Indikator disiplin kerja adalah: mematuhi semua peraturan perusahaan, penggunaan waktu secara efektif, tanggung jawab dalam pekerjaan dan tugas serta tingkat absensi

Dengan demikian tujuan dalam penelitian ini adalah untuk menganalisis: 1) Karakteristik responden (pegawai) Yayasan BMD yang meliputi jenis kelamin, usia, pendidikan dan masa kerja. 2) Tingkat kinerja, motivasi kerja dan disiplin kerja pegawai di Yayasan BMD, 3) Pengaruh variabel motivasi kerja dan disiplin kerja terhadap kinerja pegawai di Yayasan BMD, secara parsiilmaupun secara bersama-sama. 4) Variabel yang lebih dominan pengaruhnya antara motivasi kerja dan disiplin kerja terhadap kinerja karyawan di Yayasan BMD, 5) Perbedaan tingkat motivasi kerja, disiplin kerja dan kinerja pegawai menurut jenis pegawai (Guru dan Karyawan) dan masa kerja (tahun)

Berdasar uraian di depan dapat dijelaskan kerangka pikir dalam penelitan ini sebagai berikut: Menurut Hasibuan (2012) Motivasi menjadi pendorong seseorang melaksanakan suatu kegiatan guna mendapatkan hasil yang terbaik. Pegawai yang mempunyai motivasi kerja yang tinggi akan mempunyai kinerja yang tinggi pula. Indikator motivasi meliputi: pekerjaan itu sendiri, pengakuan orang lain, tanggung jawab, gaji, hubungan rekan kerja dan kondisi kerja. Kedisiplinan merupakan fungsi operatif 
MSDM yang terpenting karena semakin baik disiplin pegawai, semakin tinggi prestasi kerja yang dapat dicapainya. Disiplin kerja yang baik mencerminkan besarnya rasa tanggung jawab seseorang terhadap tugas-tugas yang diberikan kepadanya. Hal ini mendorong gairah kerja, semangat kerja, dan terwujudnya tujuan perusahaan, karyawan/pegawai, dan masyarakat. Oleh karena itu, setiap manajer selalu berusaha agar para bawahannya mempunyai disiplin yang baik. Indikator disiplin kerja meliputi: mematuhi semua peraturan perusahaan, penggunaan waktu secara efektif, tanggung jawab dalam pekerjaan dan tingkat absensi.

Kinerja adalah suatu hasil kerja yang dicapai oleh seseorang dalam melaksanakan tugas-tugas yang dibebankan kepadanya yang didasarkan atas kecakapan, pengalaman dan kesungguhan serta waktu. Indikator kinerja meliputi: kualitas kerja, inisiatif, ketepatan dan kemampuan. Kinerja karyawan dipengaruhi oleh beberapa faktor baik yang berhubungan dengan tenaga kerja itu sendiri maupun berhubungan dengan lingkungan perusahaan atau organisasi. Wexley dan Yukl (2000), mengidenfikasi faktor - faktor yang mempengaruhi kinerja antar lain adalah motivasi dan disiplin kerja.

Kerangka pikir tersebut dapat digambarkan sebagai berikut:

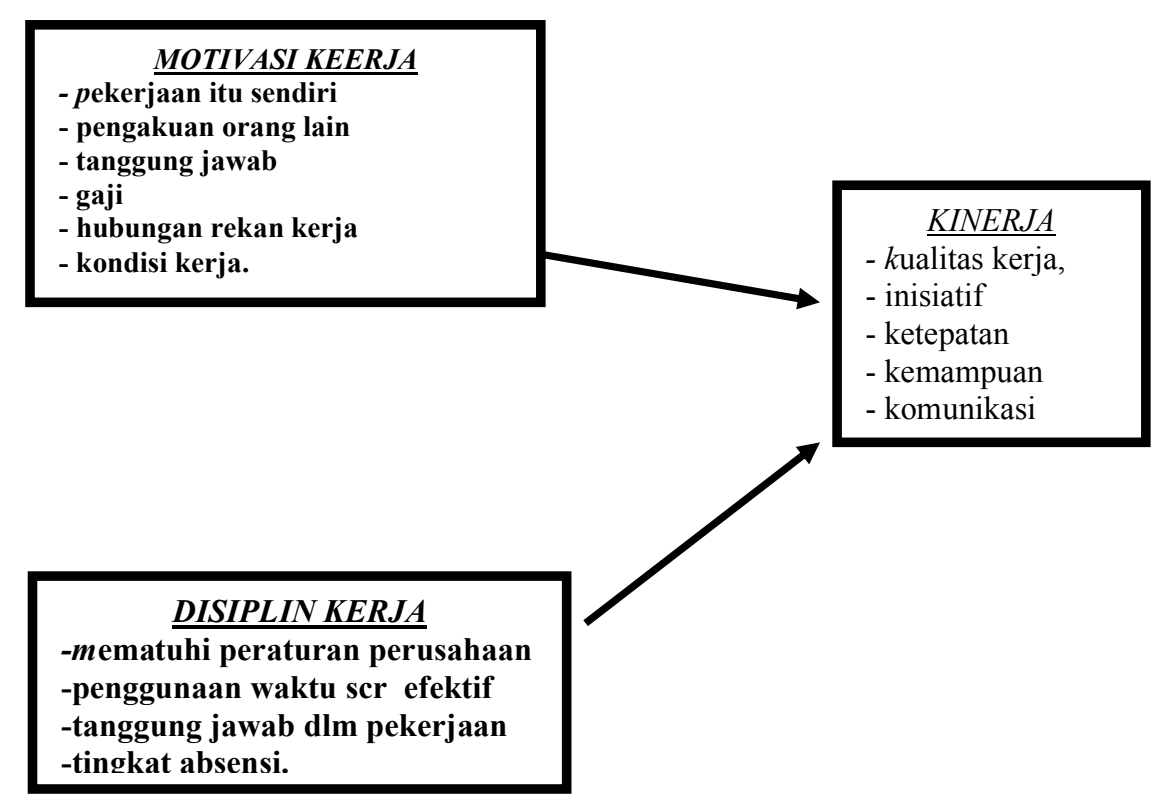

Gambar 1: Kerangka Pikir Penelitian

Berkenaan dengan kerangka pikir tersebut maka hipotesis yang dikemukakan di sini adalah:

1. Ada pengaruh Motivasi Kerja dan Disiplin Kerja terhadap Kinerja Karyawan secara parsiil maupun secara bersama-sama.

2. Ada perbedaan tingkat motivasi kerja, disiplin kerja dan kinerja pegawai menurut jenis pegawai (Guru dan Karyawan) dan masa kerja (tahun). 


\section{METODE PENELITIAN}

Penelitian dilakukan di Yayasan MBD yang bergerak di bidang pendidikan. Populasi dalam penelitian ini adalah semua pegawai yang berjumlah 70 orang. Semua populasi dijadikan responden disebut metode sensus (Sugiyono, 2010). Variabel dalam penelitian ini: Variabel bebas (independent variable) adalah motivasi kerja dan disiplin kerja. Sedang variabel tergantug (dependent variable) adalah kinerja pegawai.

Data yang diperlukan dalam penelitian ini adalah data primer dari responden dan data sekunder dari buku-buku, majalah, koran maupun instansi yang ada kaitannya dengan penelitian. Metode pengumpulan data primer digunakan "Metode Angket", sedang metode pengukurannya dengan skala Likert yaitu skala yang digunakan untuk mengukur sikap, pendapat, persepsi dari seseorang tentang fenomena sosial (Sugiyono, 2010). Jawaban dari setiap item pernyataan disediakan lima alternatif jawaban dan penilaian untuk masingmasing alternatif jawaban diberi bobot (skor): a). Sangat Tidak Setuju (STS) skor:1, b). Tidak Setuju (TS) skor 2, c). Netral (N) skor 3, d). Setuju (S) skor 4 dan e). Sangat Setuju (SS) skor 5.

Indikator yang digunakan dalam masing-masing variabel adalah: (Hasibuan, 2012) Variabel Motivasi Kerja: ada 6 indikator dengan 6 item pernyataan: 1). Pekerjaan itu sendiri: "Saya bekerja keras atas pekerjaan yang saya lakukan". 2) Pengakuan orang lain: "Pengakuan orang lain dalam organisasi membuat saya merasa memiliki" 3) Tanggung jawab: "Saya memiliki tanggungjawab besar atas pekerjaan yang saya lakukan" 4) Gaji: "Gaji yang sesuai menjadi harapan besar dalam pekerjaan saya" 5) Hubungan rekan kerja: "Saya cenderung membangun kerja sama dengan sesama teman kerja" 6). Kondisi kerja: "Kondisi pekerjaan yang kondusif menjadi faktor penting dalam menyelesaikan pekerjaan. Variabel Disiplin Kerja: ada 4 indikator dengan 4 item pernyataan:1) Mematuhi semua peraturan perusahaan: "Saya mematuhi semua peraturan yang ada dalam organisasi" 2) Penggunaan waktu secara efektif: "Saya menggunakan waktu secara efektif dalam menyelesaikan semua pekerjaan " 3) Tanggung jawab dalam pekerjaan dan tugas: "Semua pekerjaan dan tugas merupakan tanggungjawab saya yang harus diselesaikan dengan baik. 4) Tingkat absensi: "Saya tidak pernah absen dalam pekerjaan, kecuali ada hal yang tidak bisa ditinggalkan. Variabel Kinerja Pegawai: ada 5 indikator dengan 5 item pernyataan 1). Kualitas kerja: ” Memiliki kualitas yang lebih baik dari pegawai lain" 2) Ketepatan.: Dapat menyelesaikan pekerjaan dengan teliti dan tepat sesuai yang diharapkan" 3) Inisiatif: "Memiliki kreativitas dalam menjalankan tugas/pekerjaan yang menjadi tanggungjawabnya" 4) Kemampuan:"Memiliki kemampuan yang cukup tentang tugas kewajiban dan melakukannya" 5). Komunikasi: "Saya memiliki hubungan baik dengan atasan".

Uji validitas dan uji reliabilitas terhadap semua angket (pernyataan) dari 3 (tiga) variabel tersebut, telah dilakukan dengan sampel 30 orang karyawan. Uji validitas dengan menghitung korelasi Pearson Product Momen (ryx). Hasil perhitungan semua item pernyataan pada masing-masing variabel diperoleh nilai ryx-hitung lebih besar dibanding r-hitung $(0,361)$ sehingga semua dinyatakan valid). Uji reliabilitas dengan menghitung alpha Cronbach, hasilnya nilai alpha keempat variabel Motivasi Kerja, Disiplin Kerja dan Kinerja Karyawan di atas 0,8 sehingga semua variabel dinyatakan reliabel.

Metode analisis data yang digunakan dalam penelitian ini adalah analisis kualitatif dan analisis kuantitatif sebagai berikut:

1) Untuk menganalisis karakteristik responden (karyawan) digunakan analisis kualitatif Yaitu analisis yang hanya menggunakan paparan sederhana, baik menggunakan 
jumlah data maupun persentase dengan membuat distribusi frekuensi (Suharsimi Arikunto, 2006).

2) Untuk menganalisis tanggapan responden (karyawan) terhadap masing-masing variabel motivasi kerja, disiplin kerja dan kinerjan karyawan digunakan Distribusi Frekuensi dan Rata-rata Hitung (Mean) dengan interval 0,8 dan ada 5 kriteria yaitu sangat rendah, rendah, cukup, tinggi, sangat tinggi.

3) Untuk menganalisis pengaruh Motivasi kerja (X1) dan Disiplin kerja (X2) terhadap Kinerja Pegawai digunakan analisis regresi berganda (Imam Ghozali, 2008). Model persamaan regresi berganda sebagai berikut:

$$
\mathbf{Y}=\boldsymbol{\beta}_{1} \mathbf{X}_{1}+\boldsymbol{\beta}_{2} \mathbf{X}_{2}+\boldsymbol{E} \mathbf{1}
$$

4) Untuk menguji pengaruh Motivasi Kerja dan Disiplin Kerja terhadap Kinerja Pegawai secara parsiil digunakan uji $\mathrm{t}$ sedang uji secara bersama-sana digunakan uji F.

5) Untuk mengetahui variabel (X) mana yang pengaruhnya paling dominan terhadap variabel kinerja karyawan (Y) dapat dilihat dari koefisien determinasi parsial terbesar.

6) Untuk mengetahui perbedaan tingkat Motivasi Kerja, Disiplin Kerja dan Kinerja Pegawai menurut jenis pegawai dan masa kerja digunakan uji Chi Square $\left(\chi^{2}\right)$. Pengelompokan Motivasi Kerja, Disiplin Kerja dan Kinerja Pegawai adalah rendah, sedang dan tinggi. Jenis pegawai adalah Guru dan Karyawan. Sedang masa kerja adalah $<6$ tahun; $6-10$ tahun; 11-15 tahun dan $>15$ tahun.

\section{HASIL PENELITIAN DAN PEMBAHASAN}

Pengumpulan data dengan angket dilakukan terhadap 70 responden atau semua pegawai pada Yayasan BMD. Setelah dianalisis diperoleh hasil sebagai berikut:

1. Responden/pegawai terbanyak adalah: berstatus guru yaitu 53 orang $(75,71 \%)$, jenis kelamin perempuan yaitu 57 orang $(81,43 \%)$, usia berkisar antara 31 - 40 tahun yaitu 35 orang $(50 \%)$ dan berpendidikan S1 yaitu 55 orang $(78,57 \%)$, dan masa kerja berkisar antara $11-15$ tahun yaitu 27 orang $(38,57 \%)$.

2. Tanggapan responden terhadap implementasi Motivasi kerja, Disiplin kerja dan Kinerja pegawai sebagai berikut:

a. Motivasi kerja. Dari 6 item pernyataan, sebagian besar karyawan rata-rata menyatakan "setuju (S) dan sangat setuju (SS) bahwa karyawan di Yayasan BMD mempunyai motivasi kerja dalam menjalankan semua pekerjaan yang mereka lakukan dengan nilai rata-rata skor (mean) sebesar 4,41 (sangat tinggi) berarti implementasi motivasi kerjanya "sangat baik".

b. Disiplin kerja. Dari 4 item pernyataan, sebagian besar karyawan rata-rata menyatakan "setuju (S)" dan sangat setuju (SS) bahwa karyawan di Yayasan BMD mempunyai disiplin kerja dalam mentaati semua peraturan yang ada dalam organisasi dengan nilai rata-rata skor (mean) sebesar 4,45(sangat tinggi) berarti implementasi disiplin kerjanya "sangat baik".

c. Kinerja Pegawai. Dari 5 item pernyataan, sebagian besar karyawan rata-rata menyatakan "setuju (S)" dan "sangat setuju (SS)" bahwa karyawan di Yayasan BMD mempunyai kinerja dalam menyelesaikan pekerjaan-pekerjaan yang menjadi tanggung jawabnya dengan nilai rata-rata skor (mean) sebesar 4,17(tinggi) berarti implementasi kinerja " baik". 
3. Berdasar hasil analisis dengan program SPSS (Singgih Santosa, 2009) diperoleh hasil sebagai berikut:

a. Sebelum dilakukan analisis regresi berganda telah dilakukan uji asumsi dasar dan asumsi klasik. Uji asumsi dasar meliputi uji linearitas dan uji normalitas. Uji linearitas untuk hubungan variabel motivasi kerja dengan kinerja dan disiplin kerja dengan kinerja, hasilnya dinyatakan signifikan atau ada hubungan linier. Dan hasil uji normalitas menunjukkan bahwa semua variabel yang digunakan dalam penelitian ini memiliki random data yang berdistribusi normal. Sedang untuk uji asumsi klasik karena datanya bersifat "cross section" maka hanya meliputi uji hete roskedastisitas yang kesimpulannya tidak terjadi heteroskedastisitas dan uji multikolinearitas yang kesimpulannya model regresi tidak terjadi masalah mutikolinearitas atau tidak terjadi korelasi di antara variabel-variabel bebas. Dengan demikian analisis regresi berganda telah memenuhi persyaratan untuk dilanjutkan.

Hasil perhitungan analisis regresi berganda dengan SPSS sebagai berikut : Tabel. 1.1. Hasil Analisis Regresi Berganda (1)

\begin{tabular}{|c|c|c|c|c|c|c|}
\hline \multirow[b]{2}{*}{ Model } & Unstandardized & Coefficients & $\begin{array}{l}\text { Standardized } \\
\text { Coefficients }\end{array}$ & \multirow[b]{2}{*}{$\mathrm{t}$} & \multirow[b]{2}{*}{ Sig. } & Correlation \\
\hline & $\mathrm{B}$ & Std Error & Beta & & & Partial \\
\hline (CONSTANT) & 1,395 &, 537 & & 2,598 &, 012 & \\
\hline 1 MOTIVASI X & ,305 &, 117 & ,275 & 2,604 &, 011 &, 168 \\
\hline DISIPLIN $\quad X_{2}$ &, 412 &, 100 & ,434 & 4,115 &, 000 &, 000 \\
\hline
\end{tabular}

Dependent Variable: KINERJA Y

Sumber: olah data dengan SPSS, 2016

Tabel. 1.2. Hasil Analisis Regresi Berganda (2)

\begin{tabular}{|rl|r|r|r|r|r|}
\hline Model & & Sum of Squares & Df & Mean Square & F & Sig \\
\hline \multirow{4}{*}{1} & Regression & 3,839 & 2 & 1,920 & 17,969 &, $000^{\mathrm{b}}$ \\
& Residual & 7,157 & 67 &, 107 & & \\
& Total & 10,996 & 69 & & & \\
\hline
\end{tabular}

Sumber: olah data dengan SPSS, 2016

b. Persamaan regresi berganda: $\quad \mathrm{Y}=1,395+0,305 \mathrm{X}_{1}+0,412 \mathrm{X}_{2}$

$\mathrm{Y}=$ variabel kinerja $; \quad \mathrm{X}_{1}=$ variabel motivasi kerja; $\quad \mathrm{X}_{2}=$ variabel disiplin kerja

Semua koefisien regresi untuk semua variabel bertanda positip, hal ini menggambarkan bahwa jika motivasi kerja dan disiplin kerja di tingkatkan maka kinerja pegawai juga akan meningkat.

Hasil uji hipotesis terhadap koefisien regresi secara bersama-sama (Uji-F) diperoleh nilai F-hitung $=17,969$ dengan tingkat signifikansi (nilai probabilitas) $=$ 0,00 dan posisinya di bawah nilai 0,05 . Dengan demikian terbukti bahwa variabel motivasi kerja dan disiplin kerja secara bersama-sama dapat meningkatkan kinerja pegawai secara signifikan. Hal ini didukung juga dengan nilai koefisien korelasi berganda $\mathrm{R}=0,591$ (di atas 0,5 ) yang berarti korelasinya cukup kuat. Nilai koefisien determinasi berganda $\mathrm{R}^{2}=0,349=34,9 \%$ yang berarti peningkatan kinerja pegawai sebanyak $34,9 \%$ disebabkan oleh peningkatan variabel motivasi kerja dan disiplin kerja secara bersama-sama, sedang sisanya yang $65,1 \%$ disebabkan oleh hal-hal di luar variabel-variabel tersebut yang tidak masuk dalam penelitian ini. 
Hasil uji hipotesis terhadap koefisien regresi secara parsial (Uji-t) diperoleh nilai t-hitung variabel motivasi kerja $=2,604$ dengan tingkat signifikansi (nilai probabilitas) $=0,011$; nilai t-hitung variabel disiplin kerja $=4,115$ dengan tingkat signifikansi (nilai probabilitas) $=0,000$. Nilai probabilitas semua variabel posisinya berada di bawah nilai 0,05 . Dengan demikian terbukti bahwa variabel motivasi kerja dan disiplin kerja secara parsial dapat meningkatkan kinerja pegawai secara signifikan.

4. Nilai koefisien determinasi parsial $\left(\mathrm{r}^{2}\right)$ variabel disiplin kerja $=(0,449)^{2}=0,201$ lebih besar dibanding $\mathrm{r}^{2}$ variabel motivasi kerja $=(0,168)^{2}=0,028$ Dengan demikian variabel disiplin kerja pengaruhnya untuk meningkatkan kinerja pegawai lebih dominan dari pada variabel motivasi kerja.

5. Hasil perhitungan nilai $\chi^{2}$ sebagai berikut:

a. Uji perbedaan tingkat Motivasi Kerja menurut Jenis pegawai diperoleh nilai $\chi^{2}$ hitung $=0,502$ yang nilainya berada di bawah nilai $\chi^{2}$ tabel $=5,99$ dan menurut masa kerja diperoleh nilai $\chi^{2}$ hitung $=3,12$ yang nilainya berada di bawah nilai $\chi^{2}$ tabel $=$ 12,59. Dengan demikian dapat disimpulkan bahwa tidak ada perbedaan tingkat motivasi kerja menurut jenis pegawai maupun masa kerjanya.

b. Uji perbedaan tingkat Disiplin Kerja menurut Jenis pegawai diperoleh nilai $\chi^{2}$ hitung $=0,89$ yang nilainya berada di bawah nilai $\chi^{2}$ tabel $=5,99$ dan menurut masa kerja diperoleh nilai $\chi^{2}$ hitung $=3,78$ yang nilainya berada di bawah nilai $\chi^{2}$ tabel $=12,59$. Dengan demikian dapat disimpulkan bahwa tidak ada perbedaan tingkat Disiplin Kerja menurut jenis pegawai maupun masa kerjanya.

c. Uji perbedaan tingkat Kinerja Pegawai menurut Jenis pegawai diperoleh nilai $\chi^{2}$ hitung $=$ yang nilainya berada di bawah nilai $\chi^{2}$ tabel $=5,99$ dan menurut masa kerja diperoleh nilai $\chi^{2}$ hitung $=3,2$ yang nilainya berada di bawah nilai $\chi^{2}$ tabel $=$ 12,59. Dengan demikian dapat disimpulkan bahwa tidak ada perbedaan tingkat Kinerja Pegawai menurut jenis pegawai maupun masa kerjanya.

\section{KESIMPULAN DAN SARAN}

1. Dari hasil penelitian dan pembahasan dapat disimpulkan:

a. Responden/pegawai terbanyak adalah: berstatus guru yaitu 53 orang $(75,71 \%)$, jenis kelamin perempuan yaitu 57 orang $(81,43 \%)$, usia berkisar antara $31-40$ tahun yaitu 35 orang $(50 \%)$ dan berpendidikan S1 yaitu 55 orang $(78,57 \%)$, dan masa kerja berkisar antara $11-15$ tahun yaitu 27 orang $(38,57 \%)$

b. Tanggapan responden terhadap implementasi motivasi kerja: sangat baik (skor 4,41), disiplin kerja: sangat baik (skor 4,45) dan kinerja pegawai: baik (skor 4,17)

c. Terbukti ada pengaruh positif dan signifikan dari motivasi kerja $\left(\mathrm{X}_{1}\right)$ dan disiplin kerja $\left(\mathrm{X}_{2}\right)$ terhadap kinerja pegawai $(\mathrm{Y})$, secara parsial maupun bersama-sama

d. Disiplin kerja $\left(\mathrm{X}_{1}\right)$ pengaruhnya terhadap kinerja pegawai lebih dominan dibanding motivasi kerja $\left(\mathrm{X}_{2}\right)$

e. Tidak ada perbedaan tingkat motivasi kerja, disiplin kerja dan kinerja pegawai menurut jenis pekerjaannya (Karyawan atau Guru). Dan tidak ada perbedaan tingkat motivasi kerja, disiplin kerja dan kinerja pegawai menurut masa kerjanya. 


\section{Saran}

Saran yang diajukan adalah dalam upaya meningkatkan kinerja pegawai guna mencapai tujuan organisasi, sebaiknya organisasi lebih memperhatikan disiplin kerja tanpa meninggalkan moitivasi kerja. Selain itu sebaiknya juga dilakukan penelitian lebih lanjut dengan mengembangkan variabel-variabel penelitian di luar moivasi kerja dan disiplin kerja yg koefiusuien determinasi bergandanya $\left(\mathrm{R}^{2}\right)$ hanya 34,9\%. dengan demikian diharapkan bisa lebih banyak lagi kebijakan-kebijakan yang diambil organiusasi guna meningkatkan kinerja pegawai sehingga apa yang menjadi goal dari organisasi bisa tercapai.

\section{DAFTAR PUSTAKA}

Arikunto, Suharsimi. 2010. Prosedur Penelitian Suatu Pendekatan Praktek. Jakarta: Rineka Cipta.

Asmirasih, Tety. 2006. Pengaruh Pengawasan Terhadap Disiplin Kerja Pegawai Badan Kepegawaian Daerah Kabupaten Brebes, Skripsi, Semarang: Fakultas Ilmu Sosial Universitas Negeri Semarang.

Bejo, Siwanto. 2005. Manajemen Tenaga Kerja Indonesia Pendekatan Adminitratif dan Operasional. Jakarta: Bumi Aksara.

Fathoni, Abdurrahmat. 2006. Organisasi dan Manajemen Sumber Daya Manusia. Jakarta: Rineka Cipta.

Ghazali, Imam. 2008. Aplikasi Analisis Multivariate dengan Program SPSS. Semarang: Badan Penerbit Universitas Diponegoro Semarang.

Hasibuan, Malayu, S.P. 2012. Manajemen Sumber Daya Manusia. Cet 16. Jakarta :Bumi Aksara.

Indriantoro dan Bambang. 2013. Metologi Penelitian Bisnis untuk Akuntansi dan Manajemen. Yogyakarta: BPFE.

Mangkunegara, Anwar, Prabu. 2005. Evaluasi Kinerja SDM. Bandung: PT. Remaja Rosdakarya.

Muchdarsyah ,Sinungan . 2000. Produktivitas apa dan Bagaimana. Jakarta: Bumi Aksara.

Mulyasa, E, prof. Dr. H. MPd. 2003. Kurikulum Berbasis Kompetensi: Konsep, Karakteristik, dan implementasi. Bandung: Remaja Rosdakarya.

Republik Indonesia, UU RI Nomor 13 Tahun 2003, Tentang Ketenagakerjaan, Jakarta

Rivai, Veithzal, 2005. Performance Appraisal. Jakarta: PT. Raja Grafindo. 
Robbins.P.Stepenj, 2006, Perilaku Organisasi, Jakarta PTR Indeks Gramedia Group.

Sardiman A.M. 2006. Interaksi dan Motivasi Belajar Mengajar. Jakarta: PT. Rajagrafindo Persada.

Sedarmayanti, SPd. 2001. Sumber Daya Manusia dan Produktivitas Kerja. Bandung: CV. Mandar Maju.

Siagian P. Sondang. 2002. Kiat meningkatkan Produktivitas Kerja. Jakarta: Rineka Cipta. . 2005. Fungsi - Fungsi Manajerial. Jakarta: Bumi Aksara.

Simomora, Henry. 2006. Manajemen Sumber Daya Manusia, Edisi 2, Yogyakarta: STIE YKPN.

Singgih Santoso. 2009. Panduan Lengkap Menguasai Statistik dengan SPSS. Jakarta: PT. Elex Media Komputindo.

Sugiyono. 2010. Metode Penelitian Bisnis.Bandung: Alfabeta.

Uma Sekaran, 2006, Metodologi Penelitian untuk Bisnis, Edisi 4, Buku 2, Jakarta: Salemba Empat.

Waxley,dan Yukl, 2000. Perilaku Organisasi dan Psikologi Personil. Jakarta: PT. Rineka Cipta. 